\title{
Microstructures of as-Fabricated and Post Heat Treated Ti-47Al-2Nb-2Cr Alloy Produced by Selective Electron Beam Melting (SEBM)
}

\author{
Yang Guangyu, Jia Wenpeng, Zhao Pei, Jia Liang, Liu Nan, Wang Jian, \\ Tang Huiping
}

State Key Laboratory of Porous Metal Materials, Northwest Institute for Nonferrous Metal Research, Xi'an 710016, China

\begin{abstract}
The microstructures of as-fabricated and post heat treated $\mathrm{Ti}-47 \mathrm{Al}-2 \mathrm{Nb}-2 \mathrm{Cr}$ (at $\%$ ) alloy produced by selective electron beam melting (SEBM) were examined. The solidification path and the phase transformation of Ti-47Al-2Nb-2Cr alloy during SEBM process were analyzed. Results show that the microstructure is fully lamellar (FL), consisting of fine $\gamma-\mathrm{TiAl}$ and $\alpha_{2}-\mathrm{Ti}_{3} \mathrm{Al}$, which is formed in the as-fabricated TiAl specimen. Due to the rapid cooling and the cyclic heat treatment during the SEBM process, the lamellar colonies and the lamellae width become coarser and wider, respectively from the top to the bottom of the specimen, solidification takes place solely through the $\beta$ phase, and the phase transformation path is $\mathrm{L} \rightarrow \mathrm{L}+\beta \rightarrow \beta \rightarrow \beta+\alpha \rightarrow \alpha \rightarrow \alpha+\gamma$. Different post heat treatments were carried out to get a homogeneous microstructure. Results indicate that a fine and homogeneous microstructure can be achieved after oil quenching from $1250{ }^{\circ} \mathrm{C}$ and holding at $1200{ }^{\circ} \mathrm{C}$ for $2 \mathrm{~h}$.
\end{abstract}

Key words: TiAl alloy; additive manufacturing; selective electron beam melting

TiAl based alloys with low density, high specific modulus and acceptable oxidation resistance are potential structural materials in automotive and aerospace industries ${ }^{[1-3]}$. However these alloys are difficult to be processed by conventional manufacturing routes such as rolling, forging and welding for their brittleness ${ }^{[4]}$. The main methods proposed to produce TiAl based alloys are casting and powder metallurgy. But it is difficult to transform the coarse as-cast microstructure to a fine structure which has a remarkable effect on the strength and ductility. As for powder metallurgy such as HIP, the cost is too high and the mould design is difficult for complex parts ${ }^{[5]}$.

Selective electron beam melting (SEBM) is a layer-by-layer additive manufacturing technology (or called 3D printing) for metal materials ${ }^{[6]}$. The electron beam is focused and deflected by electromagnetic coils to selectively melt the metal powder following a 3D model. It can be used for the direct building of complex, functional parts designed in a $3 \mathrm{D}$ software ${ }^{[7]}$.
Recently, SEBM has been studied as a feasible way to fabricate titanium specific orthopedic implants such as femoral stems and spinal. And some research were also conducted in the fabrication of structural parts in aerospace and automotive industries such as TiAl alloy parts ${ }^{[8-10]}$. But seldom study has been done on the microstructure and the phase transformation of the progress. In the present study, Ti-47Al-2Nb-2Cr (at\%) alloy was fabricated by the SEBM process. The microstructures of the as-deposited and post heat-treated specimens were investigated.

\section{Experiment}

Ti-47Al-2Nb-2Cr (at\%) powder $(\leq 150 \mu \mathrm{m}$, spherical powder prepared by plasma rotation electrode) was used as starting material in the present investigation. Typical powder morphology is shown in Fig.1.

All fabrication experiments were conducted on a self-made

$\overline{\text { Received date: July 10, 2015 }}$

Foundation item: Science Plan Subject of Shaanxi Province Project (2014KTZB01-02-03, 2015KTCQ01-60)

Corresponding author: Tang Huiping, Ph. D., Professor, State Key Laboratory of Porous Metal Materials, Northwest Institute for Nonferrous Metal Research, Xi'an 710016, P. R. China, Tel: 0086-29-86231095, E-mail: thpfys@126.com 


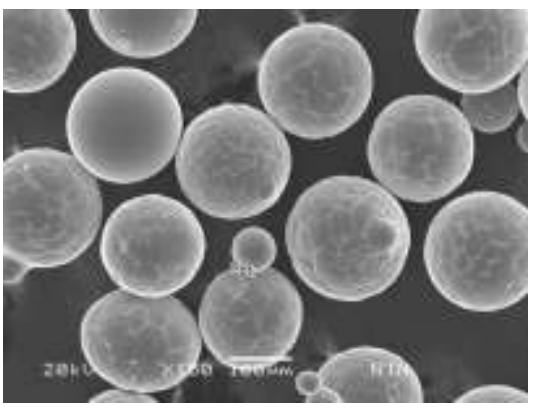

Fig.1 SEM image of Ti-47Al-2Nb-2Cr powder

SEBM machine. A $40 \mathrm{~mm} \times 40 \mathrm{~mm} \times 40 \mathrm{~mm}$ model was established by CAD and then sliced into 200 layers. The model was used to direct the layer-melt scan in the SEBM. When the fabrication process started, a $270 \mathrm{~mm} \times 270 \mathrm{~mm} \times 15$ $\mathrm{mm}$ square stainless steel plate was first heated to a temperature of $1000{ }^{\circ} \mathrm{C}$ by the electron beam, and then the Ti-47Al-2Nb-2Cr (at\%) powder flowed from the tanks at the two sides onto it. Then a $200 \mu \mathrm{m}$ thick layer of powder was spread over the plate by a rake. The powder was preheated by scanning it with the electron beam at velocity of $6000 \mathrm{~mm} / \mathrm{s}$ and a beam current ranging from 15 to $25 \mathrm{~mA}$. Then the powder layer was melted by scanning the beam at $6000 \mathrm{~mm} / \mathrm{s}$ and a beam current of 30 $\mathrm{mA}$. Upon completion of the first layer, scan melting, the bottom of the stainless steel plate was lowered by $200 \mu \mathrm{m}$, the next layer of powder was spread, and the process was repeated until the fabrication of the specimen was completed.

A series of post heat treatments (as shown in Table 1) for the SEBM alloy were conducted to get a fine and homogenous microstructure.

The as-fabricated and post heat treated specimens were cut parallel to the layer building direction to get the samples which were used for characterizations by optical metallography (OM), scanning electron microscopy (SEM), BSESEM and transmission electron microscopy (TEM). The OM sample was etched with a solution consisting of $100 \mathrm{~mL} \mathrm{H}_{2} \mathrm{O}$, $2.5 \mathrm{~mL} \mathrm{HF}$, and $5 \mathrm{~mL} \mathrm{HNO}_{3}$. The TEM sample were electropolished using a Struers Tenupol-5 dual-jet unit using a solution consisting of $0.9 \mathrm{~L}$ methanol to which $50 \mathrm{~mL} \mathrm{H}_{2} \mathrm{SO}_{4}$ was added. The electropolishing solution was cooled to $10{ }^{\circ} \mathrm{C}$ and the electropolishing voltage varied between 15 and $25 \mathrm{~V}$ at $5 \mathrm{~A}$. Phase compositions were identified by X-ray diffractometer operating at $40 \mathrm{kV}$ and $30 \mathrm{~mA}$ with $\mathrm{Cu} \mathrm{K \alpha}$ radiation.

\section{Results and Discussion}

\subsection{Microstructure of the as-fabricated Ti-47Al-2Nb-2Cr alloy}

A $40 \mathrm{~mm} \times 40 \mathrm{~mm} \times 40 \mathrm{~mm}$ Ti-47Al-2Nb-2Cr (at\%) alloy specimen was fabricated by the SEBM process. Fig. 2 shows $\mathrm{OM}$ and bright-field TEM images of the top (Fig.2a, 2b) and bottom (Fig.2c, 2d) microstructures of the SEBM-fabricated Ti-47Al-2Nb-2Cr alloy specimen. It is clear to see that the
Table1 Post heat treatment of SEBM Ti-47Al -2Nb-2Cr alloy

\begin{tabular}{cc}
\hline Sample No. & Heat treatment \\
\hline 1 & $1250{ }^{\circ} \mathrm{C}, 2 \mathrm{~h}$ air cooling \\
2 & $1300{ }^{\circ} \mathrm{C}, 10$ min air cooling \\
3 & $1250{ }^{\circ} \mathrm{C}, 10$ min oil quenching $\rightarrow$ \\
& $1200{ }^{\circ} \mathrm{C}, 2 \mathrm{~h}$ air cooling \\
\hline
\end{tabular}

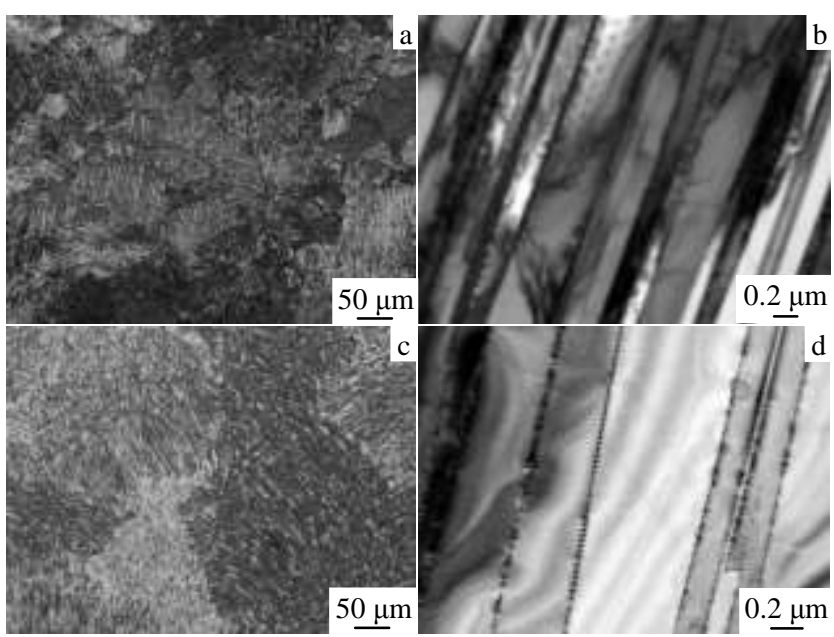

Fig.2 OM (a, c) and TEM (b, d) section images in the top (a, b) and bottom (c, d) of SEBM-fabricated specimen

microstructure of the specimen consists of extremely fine lamellar colonies in comparison to that of the conventional as-cast TiAl alloy. But the microstructures between the top and bottom parts are a little different. The microstructure of the top region is mainly composed of fine lamellar with a colony size about $50 \mu \mathrm{m}$ and lamellae size about $0.2 \mu \mathrm{m}$, which is finer than that of the bottom region with a colony size about $100 \mu \mathrm{m}$ and lamellae size about $0.4 \mu \mathrm{m}$. This is because during the fabrication, the melted layer has a temperature higher than $2000{ }^{\circ} \mathrm{C}$, due to the thermal conducting, the bottom of the specimen may experience a cyclic heat treatment at high temperature, resulting in forming coarser lamellar colonies and lamellae.

\subsection{Solidification path of Ti-47Al-2Nb-2Cr alloy during SEBM process}

From SEM-BSE images in Fig. 3 and XRD patterns in Fig.4, it can be found that the Ti-47Al-2Nb-2Cr alloy structure consists of white $\mathrm{B} 2$ phase, black $\gamma$ phase and gray $\alpha_{2}$ phase. White contrast B2 phase exists at the grain boundary and the lamellae boundary, which are clearly identified due to the segregation of heavy elements. As it was reported ${ }^{[11]}$, for casting process of TiAl alloy with concentrations of 47 at $\% \mathrm{Al}$, primary $\beta$ phase is formed first followed by the peritectic formation of the $\alpha$ phase and exhibits dentrite structures. But the SEBM Ti-47Al-2Nb-2Cr (at\%) alloy exhibits the structure consisting of relatively fine equiaxed grains, without dendrites structure. So for the SEBM Ti-47Al-2Nb-2Cr alloy, solidifycation takes place solely through the $\beta$ phase, which is 
different from the as-cast alloy and there is no peritectic

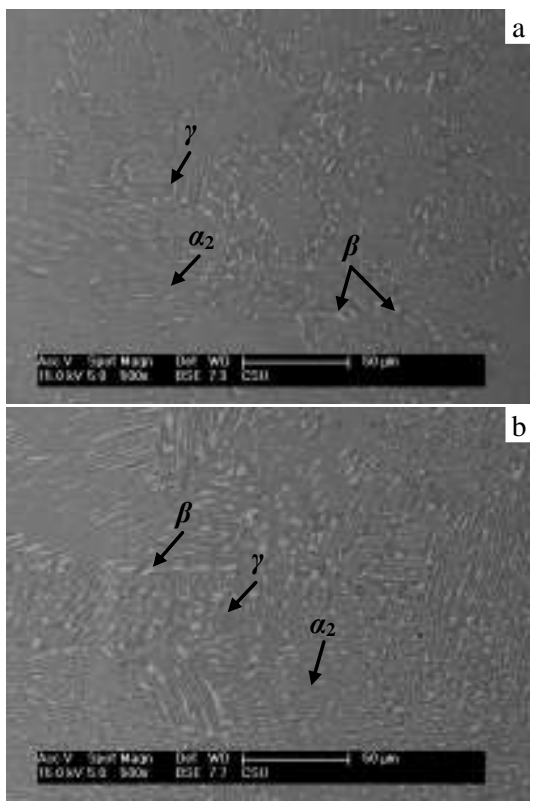

Fig.3 SEM-BSE section images for the top (a) and bottom (b) of SEBM-fabricated test specimen

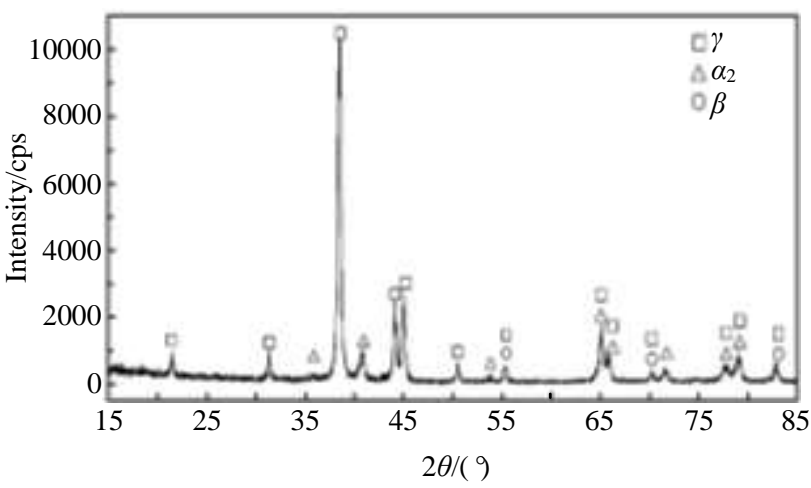

Fig.4 XRD pattern of the SEBM-fabricated test specimen

reaction. The solidification process is mainly determined by kinetic factors, since the small melt pool and the rapid cooling experience in the SEBM, the phase transformation process during solidification often occurs far from thermodynamic equilibrium. It can be seen that the morphology is similar to that of lamellar near- $\alpha \mathrm{Ti}$ binary alloy which occurs in $\beta$-solidifying. This morphology can be explained by the following phase transformation path: $\mathrm{L} \rightarrow \mathrm{L}+\beta \rightarrow \beta \rightarrow \beta+\alpha$ $\rightarrow \alpha \rightarrow \alpha+\gamma$. In the $\beta \rightarrow \beta+\alpha$ transformation, $\alpha$ platelets precipitate from the $\beta$ phase. This leads to the segregation of Ti to ribs of remaining B2 phase. Subsequently, $\gamma$ lamellae are precipitated within the $\alpha$ platelets.

\subsection{Post heat treatment of SEBM fabricated Ti-47Al- 2Nb-2Cr alloy}

As shown in Fig.2 and Fig.3, the microstructures of as-SEBM Ti-47Al-2Nb-2Cr alloy in the top and bottom parts are a little different. A series of subsequent heat treatments were performed in order to develop a fine and uniform microstructure. According to the report ${ }^{[12]}$, the $\alpha$-transus temperature of traditional Ti-47Al-2Nb-2Cr alloy is about $1350{ }^{\circ} \mathrm{C}$. Post heat treatments at $1250{ }^{\circ} \mathrm{C}$ for $2 \mathrm{~h}$ in the duplex phase field and $1300{ }^{\circ} \mathrm{C}$ for $10 \mathrm{~min}$ in the near $\alpha$ phase field were carried out. Fig.5 shows that the post heat treated microstructures are more homogeneous than the initial one, but these alloys all exhibit coarse fully lamellar microstructure, which are similar to the microstructure heat treated in the single $\alpha$ phase for the conditional Ti-47Al-2Nb-2Cr (at\%) alloy. TiAl samples prepared by the SEBM method is thermodynamic unstable because of the high thermal residual stresses. Such nonequilibrium state could lower the $\alpha$-transus temperatures of, so holding temperatures of 1250 and $1300{ }^{\circ} \mathrm{C}$ are all in the single $\alpha$-phase field, the $\alpha$-transus temperature is about $1250{ }^{\circ} \mathrm{C}$ for the SEBM Ti-47Al-2Nb-2Cr alloy, which is lower than that of the traditional Ti-47Al-2Nb-2Cr (at\%) alloy. When heat treated at single $\alpha$-phase, holding time is a critical factor for the grain size. Smaller grains are observed after holding at higher temperature $\left(1300{ }^{\circ} \mathrm{C}\right.$ ) for $10 \mathrm{~min}$, while the grains grow significantly after holding at lower temperature $\left(1250^{\circ} \mathrm{C}\right)$ for $2 \mathrm{~h}$.

Fig.5 shows that the homogenous microstructure can be achieved easily by the post heat treatment, but the grain coarsening is difficult to be controlled during the treatment, so some special treatment is necessary to get a fine and homogenous structure. The formation of "massive gamma" in TiAl alloys containing 46 to $48 \mathrm{Al}$ has been used to refine the microstructures in cast TiAl alloys for years ${ }^{[13]}$, and this way has been used in the present study. Fig.6a shows the microstructure of the Ti-47Al-2Nb-2Cr (at\%) alloy which is treated at $1250{ }^{\circ} \mathrm{C}$ for $10 \mathrm{~min}$ then is oil quenched. Massive $\gamma$ is developed from

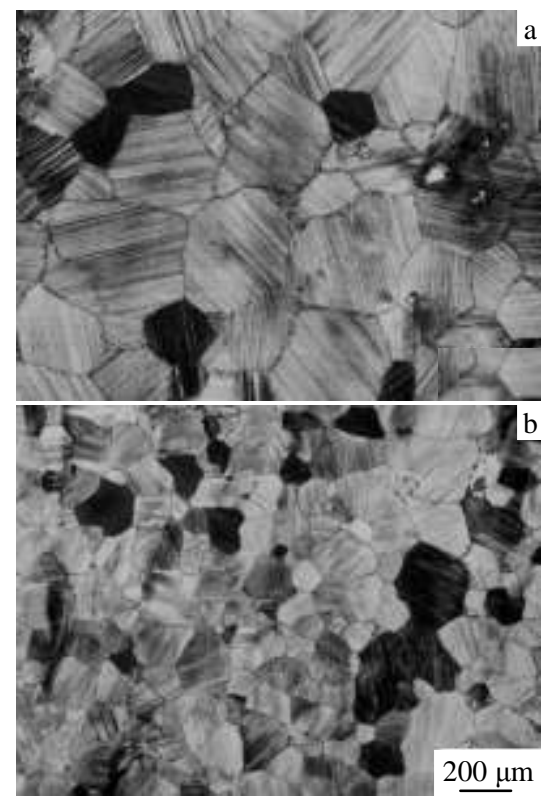

Fig.5 Microstructures of specimens heat treated at $1250{ }^{\circ} \mathrm{C}$ for 
$2 \mathrm{~h}$ (a) and at $1300{ }^{\circ} \mathrm{C}$ for $10 \mathrm{~min}(\mathrm{~b})$

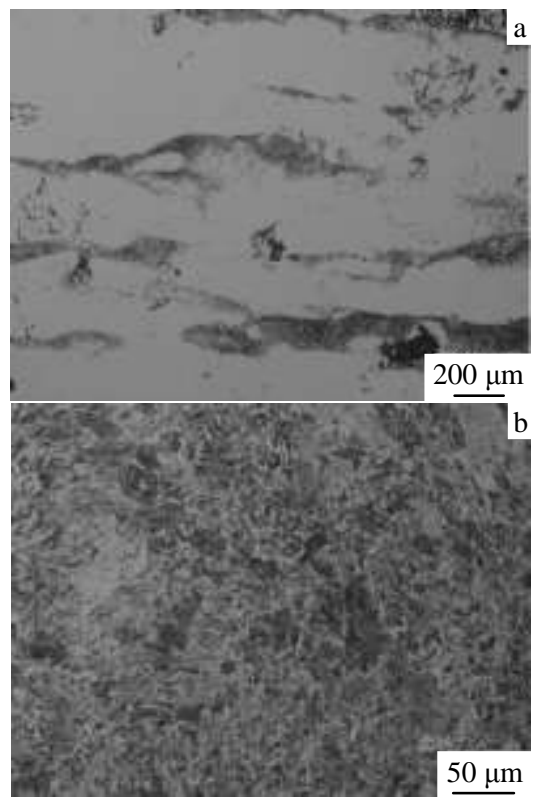

Fig.6 Microstructures of the Ti-47Al-2Nb-2Cr alloy treated at $1250{ }^{\circ} \mathrm{C}$ for $10 \mathrm{~min}$ then oil quenched (a) and followed by treating at $1200{ }^{\circ} \mathrm{C}$ for $2 \mathrm{~h}(\mathrm{~b})$

the high-temperature $\alpha$ phase and formed in a displacive transformation without long-range diffusion and consists of heavily faulted $\gamma$ phase. Fig.6b shows the microstructure of the alloy after oil quenching followed by treating, at $1200{ }^{\circ} \mathrm{C}$ for 2 h. When massive $\gamma$ is subsequently heat treated within the $(\alpha+\gamma)$ phase field, $\alpha$ will be precipitated on the massive gamma and a very fine microstructure consisting of fine $\alpha_{2}$ platelets within a $\gamma$ matrix is formed.

\section{Conclusions}

1) The lamellar colonies and lamellae all coarsen from the top to the bottom of the SEBM specimen due to the cyclic heat treatment during the SEBM process.

2) Due to the rapid cooling and the cyclic heat treatment during the SEBM process, solidification takes place solely through the $\beta$ phase, and phase transformation path is $\mathrm{L} \rightarrow \mathrm{L}+$ $\beta \rightarrow \beta \rightarrow \beta+\alpha \rightarrow \alpha \rightarrow \alpha+\gamma$.

3) Different microstructures can be got after different heat treatments. A fine and homogeneous microstructure can be achieved after oil quenching from $1250{ }^{\circ} \mathrm{C}$ followed by treating at $1200{ }^{\circ} \mathrm{C}$ for $2 \mathrm{~h}$.

\section{References}

1 Li J B, Liu Y. Intermetallics[J], 2014, 52: 49

2 Lin J P, Xu X J, Wang Y L et al. Journal of Alloys and Compound[J], 2006, 414(1-2): 175

3 Chen G L. Materials Review[J], 2000, 14(9): 51

4 Yamaguchi M, Kishida K, Inui $\mathrm{H}$ et al. Acta Metallurgica et Materialia[J], 1995, 43: 1075

5 Atkinson $\mathrm{H} \mathrm{V}$, Davies S. Metallurgical and Materials Transactions A[J], 2000, 31: 2981

6 Levy G N, Schindel R, Kruth J P. CIRP Annals-Manufacturing Technology[J], 2003, 52: 589

7 Parthasarathy J, Starly B, Raman S. Journal of Manufacturing Processes[J], 2011, 13: 160

8 Tang H P, Yang G Y, Jia W P et al. Materials Science \& Engineering $A[\mathrm{~J}], 2015,636: 103$

9 Biamino S, Penna A, Ackelid U et al. Intermetallics[J], 2011, 19: 776

10 Tang H P, Lu S L, Jia W P et al. International Journal of Powder Metallurgy[J], 2014, 50(1): 57

11 Hecht U, Witusiewicz V, Drevermann et al. Intermetallics[J], 2008, 16: 969

12 Kim Y W. Acta Metallurgica et Materialia[J], 1992, 40(6): 1121

13 Hu D, Huang A J, Wu X et al. Intermetallics[J], 2007, 15: 327

\title{
电子束选区熔化成形及后续热处理后 Ti-47Al-2Nb-2Cr 合金显微组织
}

\author{
杨广宇, 贾文鹏, 赵 培, 贾 亮, 刘 楠, 王 建, 汤慧萍 \\ (西北有色金属研究院 金属多孔材料国家重点实验室, 陕西 西安 710016)
}

\begin{abstract}
摘 要: 对电子束选区熔化成形及后续热处理后 Ti-47Al-2Nb-2Cr 合金显微组织进行了分析, 讨论了成形过程中合金凝固和固态相变过 程。结果表明, 电子束选区熔化成形 Ti-47Al-2Nb-2Cr 合金的显微为细小的 $\gamma$ - TiAl 和 $\alpha_{2}-\mathrm{Ti}_{3} \mathrm{Al}$ 形成的片层结构, 但是由于电子束选区熔 化成形过程冷却速度较快和成形过程中的热循环作用, 成形样品的片层晶团和片层宽度皆沿样品成形方向从上到下变大变宽。合金的凝 固过程通过了 $\beta$ 单相区, 并经历 $\mathrm{L} \rightarrow \mathrm{L}+\beta \rightarrow \beta \rightarrow \beta+\alpha \rightarrow \alpha \rightarrow \alpha+\gamma$ 的相变过程。为了得到均匀一致的显微组织, 对电子束选区熔化成 形样品进行了热处理, 通过 $1250{ }^{\circ} \mathrm{C}$ 油淬后 $1200{ }^{\circ} \mathrm{C}$ 保温 $2 \mathrm{~h}$, 得到了细小均匀的片层结构组织。
\end{abstract}

关键词：TiAl 基合金; 增材制造技术; 电子束选区熔化成形

作者简介: 杨广宇, 女, 1985 年生, 硕士, 西北有色金属研究院金属多孔材料国家重点实验室, 陕西 西安 710016, 电话: 029-86231095, 
Yang Guangyu et al. / Rare Metal Materials and Engineering, 2016, 45(7): 1093-1099

E-mail: yanggy0403@163.com 